\title{
STRESS AND STRAIN DISTRIBUTION IN EXPANDED CORONARY STENTS DEPENDING ON APPLIED MATERIAL
}

\author{
Aneta Idziak-Jabłońska \\ Institute of Mechanical Technology, Czestochowa University of Technology \\ Częstochowa, Poland \\ idziak-jablonska@iop.pcz.pl
}

\begin{abstract}
The aim of the study is to present mechanical characteristics of coronary stents. More specifically, stress and plastic strain present in a stent were determined depending on the pressure applied to the internal surface of the stent. The study analyses a model of a slotted-tube stent using the finite element method. The stents with two different numbers of segments and with three wall thicknesses were dealt with. The analysis was carried out for the three most popular biomaterials: austenitic steel $\mathrm{Cr}-\mathrm{Ni}-\mathrm{Mo}$, cobalt-matrix alloy $\mathrm{Co}-\mathrm{Cr}-\mathrm{W}-\mathrm{Ni}$ and titanium-matrix alloy $\mathrm{Ti}-6 \mathrm{Al}-7 \mathrm{Nb}$. Numerical analysis presented in the study provides a basis for further research and optimization of stent design. The calculations obtained in the study show that the lowest values of maximum reduced stress occur in the stent made of Cr-Ni-Mo. Furthermore, the stent made of Ti-6Al-7Nb exhibited the lowest values of plastic strain.
\end{abstract}

Keywords: slotted-tube stent, ADINA software, effective stress, plastic strain

\section{Introduction}

Since the beginnings of the introduction of stent implantation technologies, numerous models have been proposed for stents, differing in their application and types of the materials used in the design. Stents are typically made in the form of metal wiring (e.g. austenitic steel, combination of cobalt with chromium, titaniummatrix alloys), which are balloon-expandable in order to implant them in contact with the internal wall of coronary vessels [1].

Development of functional properties of coronary stents should be considered in the aspect of choosing metal biomaterials for a specific type of a stent. This is connected in particular with the miniaturization of stent design and the methods of its implantation [2]. Therefore, it is necessary to specify mechanical properties of biomaterials. An important issue is to understand the effect of the structure on biomechanical behaviour of the stent during implementation [3].

Over more than two decades of their application, stents have been gradually modified. Initially, the stents were chiefly made of stainless steel alloy (316L). 
Recent years have seen growing popularity of stents made of cobalt-chromium alloys. It enables one to reduce the diameter and cross-section of non-expanded stent. Low profile of a stent causes that the insertion through winding sections of blood vessels and tight and calcified stenosis is much easier [4]. Steels applied to the stents have a specific chemical composition, $316 \mathrm{~L}$ being a good example.

Fine grains and a low level of contamination with non-metallic inclusions results in anisothropy of mechanical properties of the material [5]. Furthermore, Cr-Ni-Mo steels ensure improved strength and ductility and reduce the vulnerability to cracking. These properties are particularly important in implants with small cross-sections, such as stents. Austenite grain size is the basic structural parameter which strongly affects mechanical properties of metal materials. Additionally, fine grains of austenite are essential due to the growing popularity of slotted tube stents. This shape of implants is obtained through laser cutting. Therefore, a proper choice of process parameters is a decisive factor that determines functional properties of implants.

Insufficient corrosion resistance and biological inertness of steel used for shortterm implants became the reason for development of new materials. The cobalt-matrix alloys came to replace the previous steels as they were characterized by a considerably higher pitting and crevice corrosion in the environment of body fluids. These properties cause that, despite the presence of the elements which would adversely affect a patient's body, the alloys might be used as long-term implants with life inside the human body of up to 15 years [6]. Cobalt-matrix alloys are characterized by higher ability of re-passivation in physiological solutions and they meet the requirements concerning a range of physicochemical properties. These alloys are numbered among biomaterials with high biocompatibility and a group of non-toxic materials [7].

Titanium alloys became another alternative. They belong to metallic materials which are widely used in medicine due to their low density and good ratio of strength to yield point. Titanium alloys are characterized by improved resistance to crevice corrosion, stress corrosion and general corrosion in the chloride medium. Compared to other metallic biomaterials, they are characterized by the best biocompatibility and the lowest Young's modulus $[8,9]$. They also show higher ability of self-passivation and improved fatigue strength, which is essential in the aspect of durability of the elements designed to remain in the human body for many years $[10,11]$. Therefore, manufacturing of any biomedical materials depends on the two properties: biofunctionality and biocompatibility [12].

The present study analysed Palmaz-Schatz stents using the finite element method. The stents used in the study were expanded with the pressure applied from the inside in order to determine their mechanical characteristics in detail. The author evaluated the effect of the analysed geometries of coronary stents while emphasizing the examination of key geometric parameters such as implantation pressure, maintaining stress and plastic strain in coronary stents for different materials. 


\section{Materials and methods}

An essential problem when developing functional properties of implants is selection of mechanical properties of the metal. Mechanical properties of biomaterial are chosen based on biomechanical characteristics determined for specific shapes of implants. These characteristics are typically obtained from numerical calculations based on finite element method using ADINA v.8.8 software [13, 14]. The numerical calculations concerned distribution of stress and plastic strain in individual elements and the types of stents. The analysis allows for the optimization of geometrical features of stents and their biomechanical properties.

The study focused on developing of the following models:

- geometrical model of a coronary stent,

- discrete model of a coronary stent,

- numerical model of a coronary stent using the finite element method.

In the final step numerical calculations were performed.

\subsection{Geometrical model}

Modelling was carried out for a slotted-tube stent $[15,16]$. Total length of the stent was $\mathrm{L}=12 \mathrm{~mm}$, whereas the dimensions of an individual parameter depending on the number of segments are presented in Figure 1. The internal radius of the stent studied was $\mathrm{R}=0.8 \mathrm{~mm}$. Three stents with different wall thicknesses were analysed: $G=0.08,0.1$ and $0.12 \mathrm{~mm}$. The individual lengths of the stent $(\mathrm{D} 1, \mathrm{D} 2$, D3, D4) were not changed with the increase in the number of segments. The variable parameters were KL1, KL2 (angles of connectors) and KP1 and KP2 (angles of wires): their values were changed with the number of segments.

\subsection{FEM analyses - discretization}

A grid with elements was generated to obtain geometrical models in order to carry out calculations by means of the finite element method [14, 17]. Discretization was carried out by means of the element of the 3D SOLID type and the analysed cases were discretized with eight-node elements. The number of nodes in the models analysed ranged from 95445 to 159075 for the stents with 9 to 15 segments, respectively. One segment of the stent contained 6120 elements of the 3D type. The total number of 3D elements obtained for the cases studied was from 55188 to $97980[16,18]$. Migliavacca et al. [17] demonstrated that numerical simulations of stents are susceptible to improvement of FEM grid; validation of FEM grid revealed that the current grid was sufficient for further analysis.

Figure 2 presents an example of a geometrical model of a coronary stent with the superimposed finite element mesh in the non-expanded (Fig. 2a) and expanded (Fig. 2b) stent. At another stage of preparations of the model for numerical calculations, the expansion pressure was applied to the stent. To simulate actual conditions 
of a surgical procedure, the expansion pressure was applied to the internal surface of the stent, which is presented in the Figure 2c.

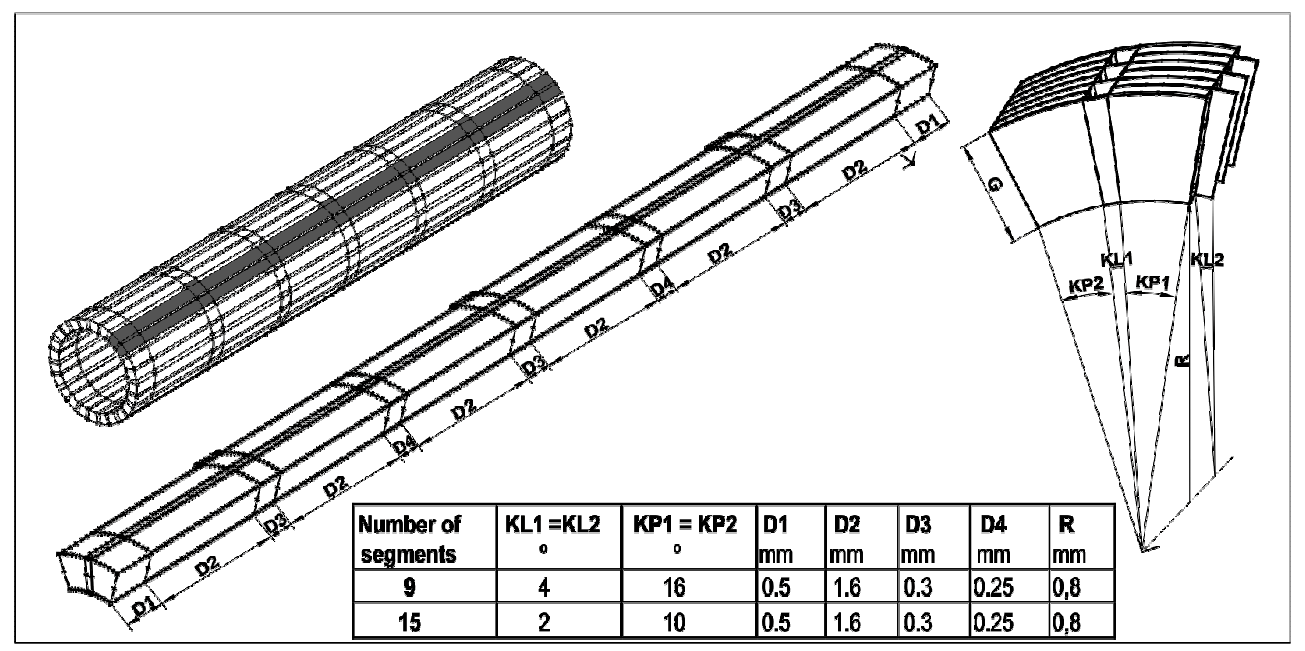

Fig. 1. Example geometrical model and dimensions of individual stent parameters

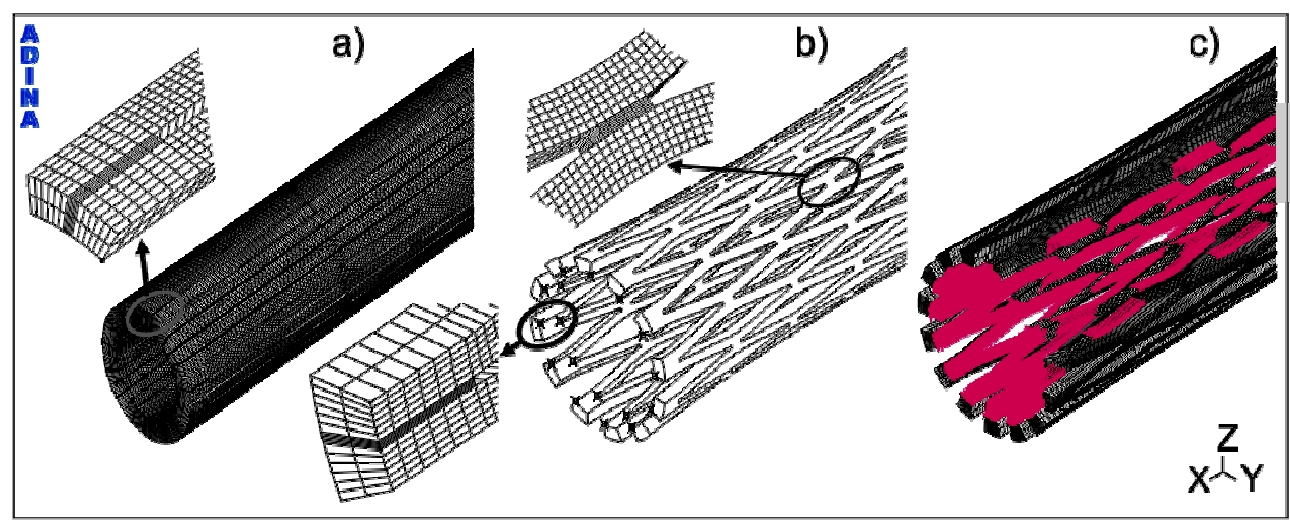

Fig. 2. Calculation model of a coronary stent: a) with the superimposed finite element mesh in the non-expanded stent, b) with the superimposed finite element mesh in the expanded stent, c) pressure distribution during expansion

\subsection{Material model}

An elastic-plastic model of material with isotropic strengthening was adopted in the analysis of stents. Mechanical properties of the material studied were adopted within the ranges defined by the standards: PN-ISO 5832-1 for steel (316L), PN-ISO 5832-5 for cobalt-matrix alloy (L605) and ASTM F1295 $(\alpha+\beta)$ for titanium-matrix alloy Ti-6Al-7Nb. Table 1 contains material data adopted for the study. 
Table 1

Material properties for the models studied

\begin{tabular}{|l|c|c|c|}
\hline \multirow{2}{*}{\multicolumn{1}{|c|}{ Material properties }} & \multicolumn{3}{c|}{ Material } \\
\cline { 2 - 4 } & Cr-Ni-Mo & Co-Cr-W-Ni & Ti-6Al-7Nb \\
\hline Young's modulus E $[\mathrm{MPa}]$ & 205000 & 243000 & 106000 \\
\hline Poisson's ratio $v$ & 0.33 & 0.3 & 0.35 \\
\hline Tensile strength $\mathrm{R}_{\mathrm{m}}[\mathrm{MPa}]$ & 470 & 917 & 1000 \\
\hline Yield point $\mathrm{R}_{\mathrm{p} 0.2}[\mathrm{MPa}]$ & 195 & 476 & 900 \\
\hline Max. allowable effective plastic strain & 0.4 & 0.65 & 0.12 \\
\hline Density $\rho\left[\mathrm{kg} / \mathrm{m}^{3}\right]$ & 7850 & 9270 & 4510 \\
\hline
\end{tabular}

\section{Results}

Table 2 presents the results of the numerical calculations. Simulations were carried out by using analysed stents with two different numbers of segments ( 9 and 15). The stents with wall thickness of $0.08,0.1$ and $0.12 \mathrm{~mm}$ were analysed in the study. All the simulations were carried out for three materials: austenitic steel 316L: Cr-Ni-Mo, cobalt-matrix alloy: Co-Cr-W-Ni and titanium-matrix alloy: Ti-6Al-7Nb.

Table 2

Results of numerical calculations

\begin{tabular}{|c|c|c|c|c|c|c|c|c|}
\hline \multirow{4}{*}{\multicolumn{2}{|c|}{$\begin{array}{c}\text { Mechanical } \\
\text { properties }\end{array}$}} & \multirow{4}{*}{ Material } & \multicolumn{6}{|c|}{ Number of segments in the stent } \\
\hline & & & \multicolumn{3}{|c|}{9 segments } & \multicolumn{3}{|c|}{15 segments } \\
\hline & & & \multicolumn{6}{|c|}{ Stent wall thickness $\mathrm{G}[\mathrm{mm}]$} \\
\hline & & & 0.08 & 0.1 & 0.12 & 0.08 & 0.1 & 0.12 \\
\hline \multicolumn{2}{|c|}{ Expansion pressure $\mathrm{p}$ [MPa] } & \multirow{4}{*}{ Cr-Ni-Mo } & 0.191 & 0.251 & 0.323 & 0.071 & 0.093 & 0.117 \\
\hline \multirow{2}{*}{$\begin{array}{l}\text { Effective stress } \sigma_{\text {sr. }} \\
{[\mathrm{MPa}]}\end{array}$} & MAX & & 362.8 & 358.7 & 350.9 & 339.7 & 334.8 & 330.2 \\
\hline & MIN & & 8.596 & 5.322 & 0.959 & 1.070 & 0.182 & 0.193 \\
\hline \multicolumn{2}{|l|}{ Plastic strain $\varepsilon$} & & 0.156 & 0.155 & 0.154 & 0.072 & 0.071 & 0.070 \\
\hline \multicolumn{2}{|c|}{ Expansion pressure $\mathrm{p}$ [MPa] } & \multirow{4}{*}{ Co-Cr-W-Ni } & 0.418 & 0.545 & 0.688 & 0.155 & 0,204 & 0,257 \\
\hline \multirow{2}{*}{$\begin{array}{l}\text { Effective stress } \sigma_{\text {sr. }} \\
{[\mathrm{MPa}]}\end{array}$} & MAX & & 847.7 & 840.8 & 843.3 & 829.9 & 805.8 & 782.0 \\
\hline & MIN & & 17.11 & 3.025 & 1.798 & 0.508 & 0.603 & 0.506 \\
\hline \multicolumn{2}{|l|}{ Plastic strain $\varepsilon$} & & 0.159 & 0.155 & 0.151 & 0.069 & 0.066 & 0,064 \\
\hline \multicolumn{2}{|c|}{ Expansion pressure $\mathrm{p}$ [MPa] } & \multirow{4}{*}{ Ti-6Al-7Nb } & 0.557 & 0.763 & 0,984 & 0.2 & 0.269 & 0.345 \\
\hline \multirow{2}{*}{$\begin{array}{l}\text { Effective stress } \sigma_{\text {sr. }} \\
{[\mathrm{MPa}]}\end{array}$} & MAX & & 1214.0 & 1229.0 & 1245.0 & 1235.0 & 1270.0 & 1265.0 \\
\hline & MIN & & 2.206 & 2.314 & 2.242 & 0.589 & 0.395 & 0.219 \\
\hline \multicolumn{2}{|l|}{ Plastic strain $\varepsilon$} & & 0.114 & 0.117 & 0.117 & 0.026 & 0.025 & 0,026 \\
\hline
\end{tabular}


Adopted by reference to the actual conditions of the course of treatment, the stent is expanded to a diameter of $3.0 \mathrm{~mm}$, i.e. which corresponds to the inner diameter of healthy coronary arteries. The expansion pressure was applied to the internal surface of the stent and was defined as a pressure used in the stent to reach the expected diameter. This pressure is necessary for the plastic strain to be reached in the studied material. The pressure for all the analysed cases ranged from 0.07 to $0.98 \mathrm{MPa}$. For a $\mathrm{Cr}-\mathrm{Ni}$-Mo stent, pressures during expansion ranged from 0.07 to $0.32 \mathrm{MPa}$, whereas for a $\mathrm{Co}-\mathrm{Cr}-\mathrm{W}-\mathrm{Ni}$ stent these values were from 0.155 to $0.688 \mathrm{MPa}$. In order for a Ti-6Al-7Nb stent to achieve the expected diameter, it required pressures from 0.2 to $0.984 \mathrm{MPa}$. For the 9-segment and 15-segment stents, expansion pressure (Fig. 3a, b) rose with the increase in stent wall thickness.

As results from the Figure 3, the lowest expansion pressures were obtained for the Cr-Ni-Mo stent, whereas the highest values were found for the Ti-6Al-7Nb stent.
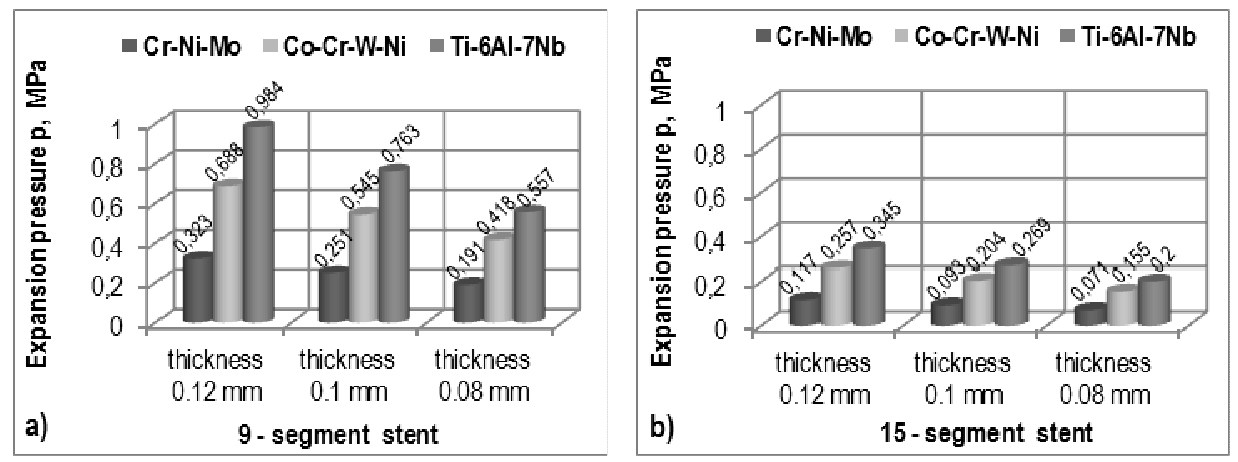

Fig. 3. Expansion pressure: a) 9-segment stent, b) 15-segment stent

The next step was to determine the maximum stress for averaged nodes. Varied stress distribution was obtained for individual types of stents, illustrated in Figure 4. The lowest stress was found for the 15-segment stent made of Cr-Ni-Mo steel, with wall thickness of $0.12 \mathrm{~mm}$. The lowest maximum stress was observed for $316 \mathrm{~L}$ steel, whereas the stent made of the titanium-matrix alloy exhibited the highest values. Figure 4 shows that the cobalt-matrix stent had approximately 2.5 times higher stress compared to the Cr-Ni-Mo stent. Furthermore, stress in the stent made of Ti-6Al-7Nb was by about 3.5 times higher than the stress obtained for the stent made of $316 \mathrm{~L}$.

Minimum reduced stress for all the analysed cases ranged from 0.18 to $17.1 \mathrm{MPa}$. The lowest stress was found in the 15-segment stent made of Cr-Ni-Mo (0.18 MPa). Higher values of minimum stress were observed in the stent made of Co-Cr-W-Ni. The stent with the lowest number of segments exhibited stress ranging from 3 to $17 \mathrm{MPa}$. The results obtained for the minimum reduced stress in the nodes are presented in Figure 5. 

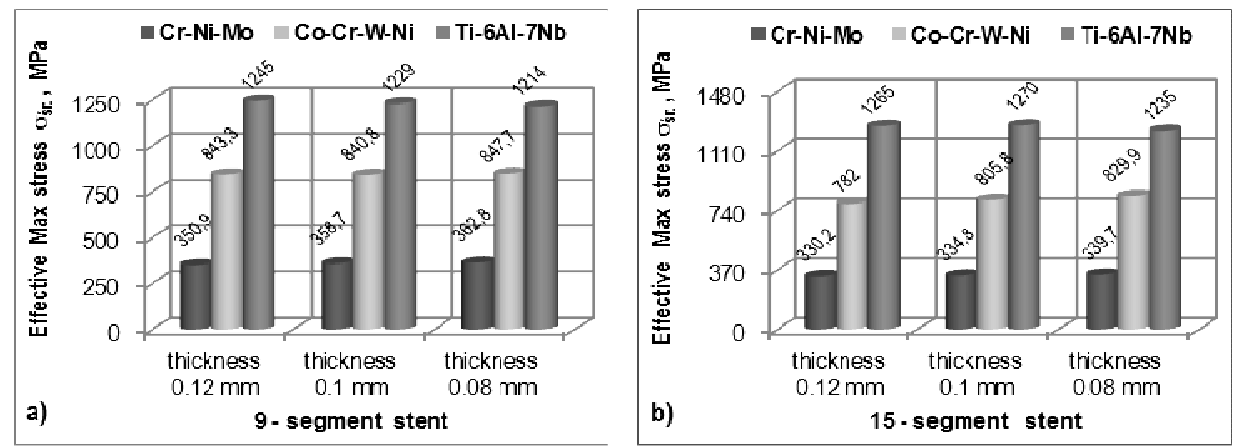

Fig. 4. Mean reduced maximum stress in the nodes: a) 9-segment stent, b) 15-segment stent
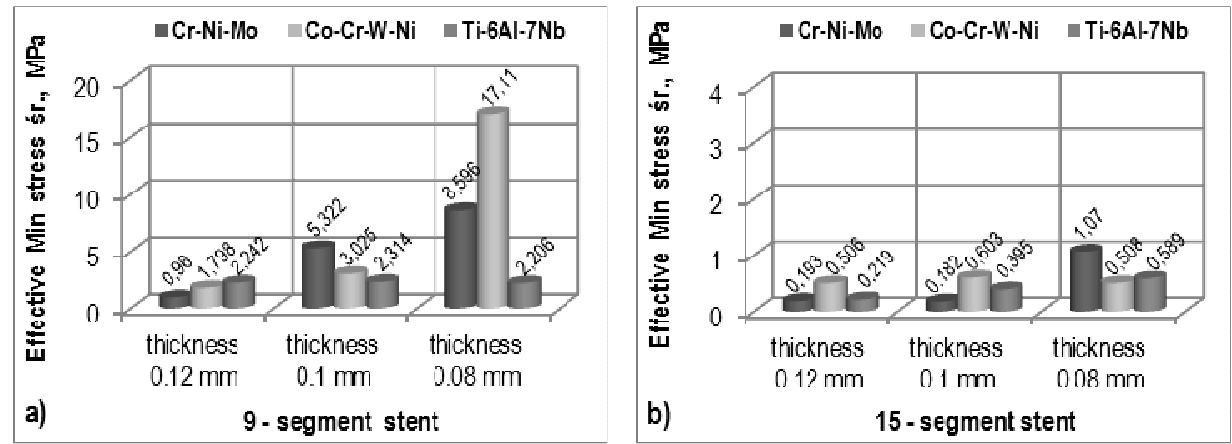

Fig. 5. Mean reduced minimum stress in the nodes: a) 9-segment stent, b) 15-segment stent

Since the values of reduced stress exceed the yield strength values for the materials used, this caused permanent deformation of geometry of the stent studied. This condition is necessary for proper process of implantation. Maximum stress was observed in the area presented in Figure 6.

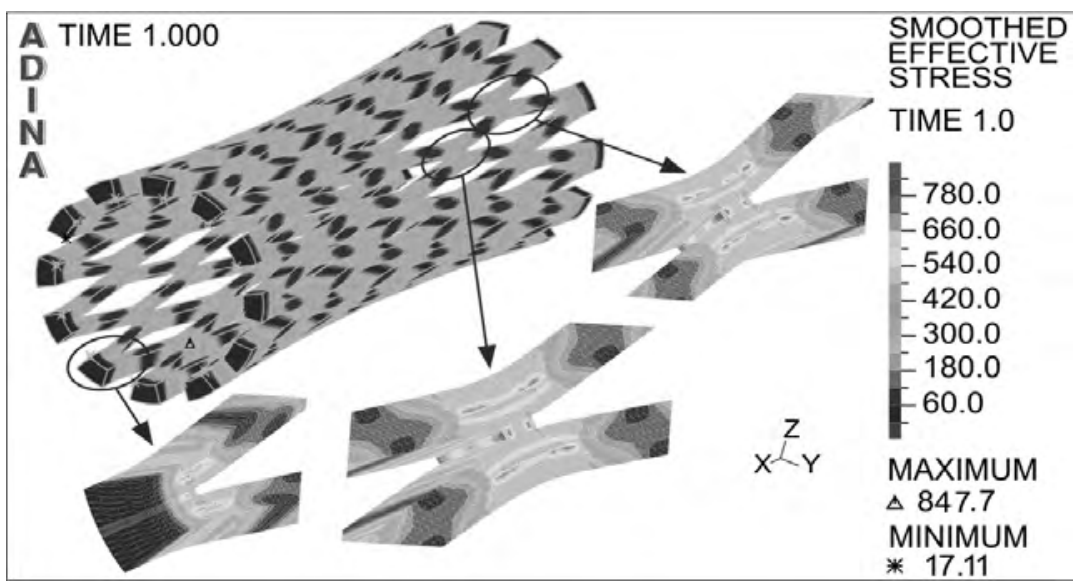

Fig. 6. Map of the reduced stress for 9-segment stent made of Co-Cr-W-Ni alloy with wall thickness of $0.08 \mathrm{~mm}$ 
Non-homogeneity of plastic strain distribution is presented in Figure 7. The simulations carried out in this study show that the lowest values of plastic strain were found in the stent made of the titanium-matrix alloy (Ti-6Al-7Nb), with the lowest plastic strain $(\varepsilon=0.025)$ observed for the stent with the highest number of segments. Furthermore, the greatest plastic strain was found in the Co-Cr-W-Ni stent, where it was $\varepsilon=0.159$. The difference between the highest and lowest plastic strain in the study was $\Delta=0.134$.
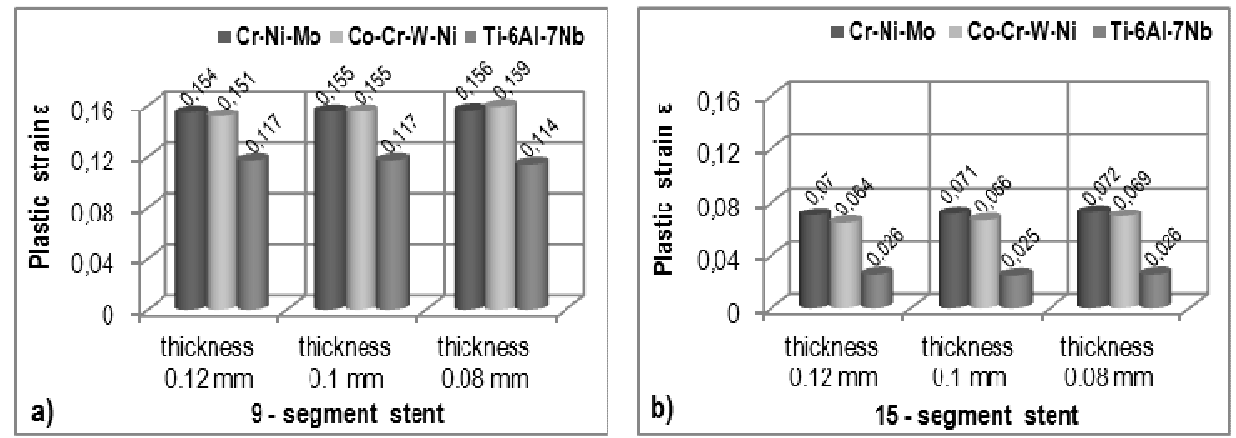

Fig. 7. Plastic strain in the analysed cases: a) 9-segment stent, b) 15 -segment stent

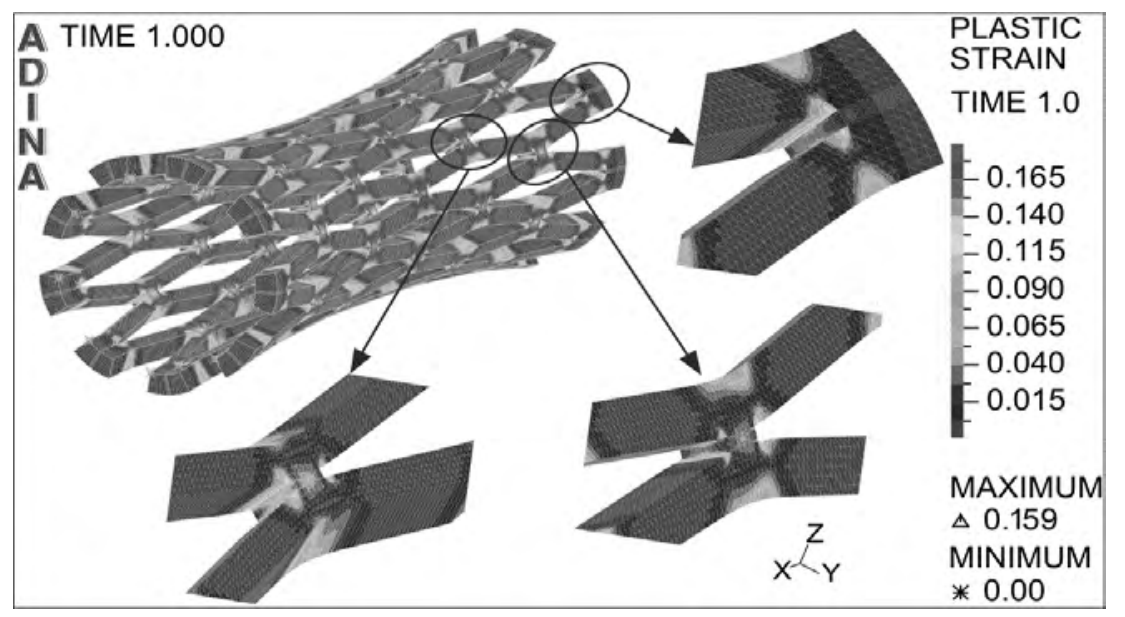

Fig. 8. Distribution of plastic strain for 9-segment stent made of Co-Cr-W-Ni alloy with wall thickness of $0.08 \mathrm{~mm}$

Maximum plastic strain was observed in the stents' forkings, which is presented in Figure 8.

\section{Conclusions}

The results obtained from the biomechanical analysis of coronary stents carried out in the present study, based on finite element method represent useful informa- 
tion with respect to modification of geometry, selection of mechanical properties and material properties of the stent.

The simulations carried out in the study lead to the following conclusions:

- values of the effective stresses exceeded the yield strength for the materials chosen, a permanent deformation of the geometry of the stent examined was observed, which represents the precondition for proper implantation of the stent in a coronary vessel. The highest level of stresses was found in stent connections;

- the lowest plastic strain occurred in the stent made of material with the lowest Young's modulus i.e. in Ti-6Al-7Nb stent, whereas the highest plastic strain was observed in the stent made of cobalt (with the highest Young's modulus);

- Cr-Ni-Mo stent was characterized by the lowest values of the reduced stress compared to the stress obtained for two other materials analysed in the study. In terms of the stent made of stainless steel it was necessary to apply the lowest expansion pressure;

- Ti-6Al-7Nb stent received the highest value of maximum stress approximately $1200 \mathrm{MPa}$. The stent made of titanium-matrix alloy also showed the lowest plastic strain among the three biomaterials analysed. The Ti-6Al-7Nb stent required a relatively high pressure to expand until reaching the expected diameter.

Looking at the results obtained from the numerical simulations it can be concluded that if the structure of a stent is thicker (more segments), improved mechanical properties can be obtained i.e. lower stresses and strains.

The analysis provides the basis for designing stents in the future.

\section{References}

[1] Walke W., Paszenda Z., Marciniak J., Optymalizacja cech geometrycznych stentu wieńcowego z wykorzystaniem metody elementów skończonych, 12th International Scientific Conference Achievements in Mechanical \& Materials Engineering 2003, 1011-1016.

[2] Sene N., Balland P., Arrieux R., Numerical study of the micro-formability of thin metallic materials: virtual micro-forming limit diagrams, Archives of Civil and Mechanical Engineering 2011, $11,2,421-435$.

[3] Paszenda Z., Optymalizacja geometrii i własności mechanicznych stentu wieńcowego ze stali Cr-Ni-Mo, Inżynieria Biomateriałów 2005, 45, 5-11.

[4] Nawrat Z., Bioinżynieria i informatyka medyczna a postępy kardiochirurgii - programy ekspertowe, symulacje, protezy i roboty, Biocyberenetyka i Inżynieria Biomedyczna 2000, Tom 7. Systemy komputerowe i telemetryczne, Akademicka Oficyna Wydawnicza EXIT, Warszawa 2002, 524-542.

[5] Paszenda Z., Problematyka tworzyw metalowych stosowanych na implanty w kardiologii zabiegowej, Inżynieria Biomateriałów 2001, 21, 3-9.

[6] Marciniak J., Paszenda Z., Walke W., Kaczmarek M., Tyrlik-Held J., Kajzer W., Stenty w chirurgii małoinwazyjnej, Wydawnictwo Politechniki Śląskiej, Gliwice 2006.

[7] Marciniak J., Biomateriały, Wydawnictwo Politechniki Śląskiej, Gliwice 2002.

[8] Wang K., The use of titanium for medical applications in the USA, Materials Science and Engineering A 1996, 213, 134-137. 
[9] Adamus J., Gierzyńska-Dolna M., Tytan współczesnym materiałem stosowanym na implanty, Inżynieria Materiałowa 2012, maj-czerwiec, 3, 189-192.

[10] Caram R., Chares R.R., Influence of the $\mathrm{Nb}$ and $\mathrm{Al}$ content on the mechanical properties of Ti-Al-Nb alloys, Materials for Medical Engineering 2001, 2, 119-125.

[11] Niinomi M., Recent research and development in titanium alloys for biomedical applications and healthcare goods, Science and Technology of Advanced Materials 2003, 4, 445-454.

[12] Etave F., Finet G., Boivina M., Boyer J-C., Rioufol G., Thollet G., Mechanical properties of coronary stents determined by using finite element analysis, Journal of Biomechanics 2001, 34, 1065-1075.

[13] Majchrzak E., Mochnacki B., Numerical modelling of heat transfer between blood vessels (artery and vein) and biological tissue, IV European Conference on Computational Mechanics ECCM, Paris 2010, 1-7.

[14] Migliavacca F., Petrini L., Montanari V., Quagliana I., Auricchio F., Dubini G., A predictive study of the mechanical behaviour of coronary stents by computer modeling, Medical Engineering \& Physics 2005, 27, 13-18.

[15] Ciekot A., Idziak-Jabłońska A., Lacki P., Optimization of dogboning phenomenon of the coronary artery stent, Scientific Research of the Institute of Mathematics and Computer Science, Prace Naukowe Instytutu Matematyki i Informatyki Politechniki Częstochowskiej 2012, 2(11), 25-31.

[16] Idziak-Jabłońska A., Lacki P., Analiza wpływu ilości segmentów i grubości stentu wieńcowego na jego właściwości mechaniczne, [in:] Monografia Mechanika w Medycynie 11(2012), eds. M. Korzyński, J. Cwanek, Oficyna Wydawnicza Politechniki Rzeszowskiej, Rzeszów 2012, 87-94.

[17] Migliavacca F., Petrini L., Colombo M., Auricchio F., Pietrabissa R., Mechanical behaviour of coronary stents investigated through the finite element method, Journal of Biomechanics 2002, 35, 803-811.

[18] Idziak-Jabłońska A., Lacki P., Major R., Effect of material and geometry on dogboning in coronary stent, Inżynieria Materiałowa 2013, 4, 194, 269-272. 